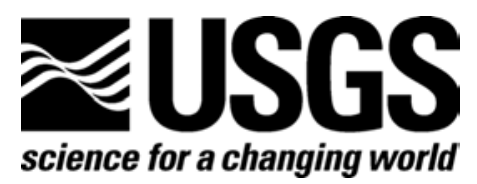

In cooperation with the Harris-Galveston Subsidence District, City of Houston, Fort Bend Subsidence District, and Lone Star Groundwater Conservation District

\title{
Water-Level Altitudes 2007 and Water-Level Changes in the Chicot, Evangeline, and Jasper Aquifers and Compaction 1973-2006 in the Chicot and Evangeline Aquifers, Houston-Galveston Region, Texas
}

By Mark C. Kasmarek and Natalie A. Houston

Scientific Investigations Map 2968 


\section{U.S. Department of the Interior \\ DIRK KEMPTHORNE, Secretary}

\section{U.S. Geological Survey \\ Mark D. Myers, Director}

U.S. Geological Survey, Reston, Virginia: 2007

For product and ordering information:

World Wide Web: http://www.usgs.gov/pubprod

Telephone: 1-888-ASK-USGS

For more information on the USGS - the Federal source for science about the Earth, its natural and living resources, natural hazards, and the environment:

World Wide Web: http://www.usgs.gov

Telephone: 1-888-ASK-USGS

Suggested citation:

Kasmarek, M.C., and Houston, N.A., 2007, Water-level altitudes 2007 and water-level changes in the Chicot, Evangeline, and Jasper aquifers and compaction 1973-2006 in the Chicot and Evangeline aquifers, HoustonGalveston region, Texas: U.S. Geological Survey Scientific Investigations Map 2968, 159 p., 18 sheets.

Any use of trade, product, or firm names is for descriptive purposes only and does not imply endorsement by the U.S. Government.

Although this report is in the public domain, permission must be secured from the individual copyright owners to reproduce any copyrighted material contained within this report. 


\section{Contents}

Abstract

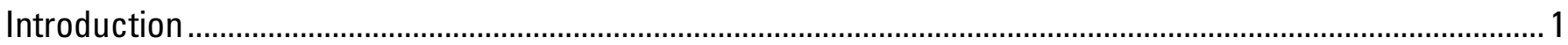

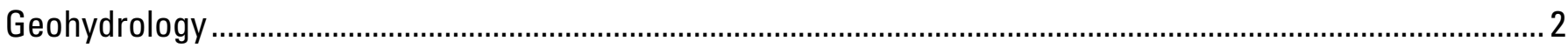

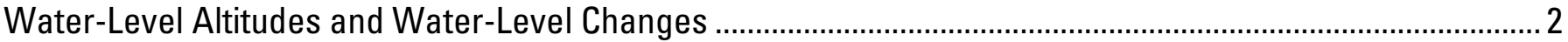

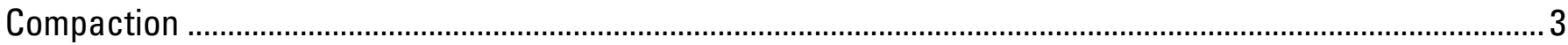

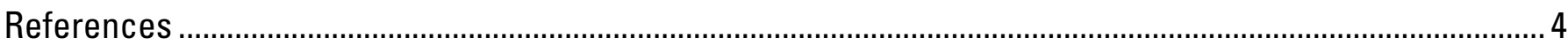

Appendix —Well Location Maps ............................................................................................................. 4

\section{Figures}

Sheets 1-17. Maps showing:

1. Approximate water-level altitudes in the Chicot aquifer, Houston-Galveston region, Texas, JanuaryMarch 2007

2. Water-level changes in the Chicot aquifer, Houston-Galveston region, Texas, 2006-07

3. Approximate water-level changes in the Chicot aquifer, Houston-Galveston region, Texas, 2002-07

4. Approximate water-level changes in the Chicot aquifer, Houston-Galveston region, Texas, 1990-2007

5. Approximate water-level changes in the Chicot aquifer, Houston-Galveston region, Texas, 1977-2007

6. Approximate water-level altitudes in the Evangeline aquifer, Houston-Galveston region, Texas, January-March 2007

7. Water-level changes in the Evangeline aquifer, Houston-Galveston region, Texas, 2006-07

8. Approximate water-level changes in the Evangeline aquifer, Houston-Galveston region, Texas, 2002-07

9. Approximate water-level changes in the Evangeline aquifer, Houston-Galveston region, Texas, 19902007

10. Approximate water-level changes in the Evangeline aquifer, Houston-Galveston region, Texas, 19772007

11. Approximate water-level altitudes in the Jasper aquifer, Houston-Galveston region, Texas, JanuaryMarch 2007

12. Water-level changes in the Jasper aquifer, Houston-Galveston region, Texas, 2006-07

13. Approximate water-level changes in the Jasper aquifer, Houston-Galveston region, Texas, 2002-07

14. Approximate water-level changes in the Jasper aquifer, Houston-Galveston region, Texas, 2000-2007

15. Approximate water-level altitudes in the Jasper aquifer, greater Houston area, Texas, 2000

16. Approximate water-level altitudes in the Jasper aquifer, greater Houston area, Texas, 2002

17. Location of borehole extensometer sites, Houston-Galveston region, Texas

18. Graphs showing measured compaction of subsurface material, 1973-2006, at borehole extensometer sites shown in figure 17

\section{Tables}

1. Data for figure 1, approximate water-level altitudes in the Chicot aquifer, Houston-Galveston region, Texas, January-March 2007

2. Data for figure 2, water-level changes in the Chicot aquifer, Houston-Galveston region, Texas, 2006-07

3. Data for figure 3, approximate water-level changes in the Chicot aquifer, Houston-Galveston region, Texas, 2002-07 
4. Data for figure 4, approximate water-level changes in the Chicot aquifer, Houston-Galveston region, Texas, 1990-2007

5. Data for figure 5, approximate water-level changes in the Chicot aquifer, Houston-Galveston region, Texas, 1977-2007

6. Data for figure 6, approximate water-level altitudes in the Evangeline aquifer, Houston-Galveston region, Texas, January-March 2007

7. Data for figure 7, water-level changes in the Evangeline aquifer, Houston-Galveston region, Texas, 200607

8. Data for figure 8, approximate water-level changes in the Evangeline aquifer, Houston-Galveston region, Texas, 2002-07

9. Data for figure 9, approximate water-level changes in the Evangeline aquifer, Houston-Galveston region, Texas, 1990-2007

10. Data for figure 10, approximate water-level changes in the Evangeline aquifer, Houston-Galveston region, Texas, 1977-2007

11. Data for figure 11, approximate water-level altitudes in the Jasper aquifer, Houston-Galveston region, Texas, January-March 2007

12. Data for figure 12, water-level changes in the Jasper aquifer, Houston-Galveston region, Texas, 2006-07 13. Data for figure 13, approximate water-level changes in the Jasper aquifer, Houston-Galveston region, Texas, 2002-07

14. Data for figure 14, approximate water-level changes in the Jasper aquifer, Houston-Galveston region, Texas, 2000-2007

15. Data for figure 15, approximate water-level altitudes in the Jasper aquifer, Houston-Galveston region, Texas, January-March 2000

16. Data for figure 16, approximate water-level altitudes in the Jasper aquifer, Houston-Galveston region, Texas, January-March 2002

17. Data for figure 18, measured compaction of subsurface material, 1973-2006, at borehole extensometer sites
A. Lake Houston
B. Northeast
C. Southwest
D. East End
E. Addicks
F. Johnson Space Center
G. Texas City-Moses Lake
H. Baytown C-1
I. Baytown C-2
J. Seabrook
K. Clear Lake
L. Pasadena

\section{VERTICAL DATUM}

Vertical coordinate information is referenced to the National Geodetic Vertical Datum of 1929 (NGVD 29).

Horizontal coordinate information is referenced to the North American Datum of 1927 (NAD 27) 


\title{
Water-Level Altitudes 2007 and Water-Level Changes in the Chicot, Evangeline, and Jasper Aquifers and Compaction 1973-2006 in the Chicot and Evangeline Aquifers, Houston-Galveston Region, Texas
}

\author{
By Mark C. Kasmarek and Natalie A. Houston
}

\begin{abstract}
This report, done in cooperation with the Harris-Galveston Subsidence District, the City of Houston, the Fort Bend Subsidence District, and the Lone Star Groundwater Conservation District, is one in an annual series of reports that depicts water-level altitudes and water-level changes in the Chicot, Evangeline, and Jasper aquifers, and compaction in the Chicot and Evangeline aquifers in the Houston-Galveston, Texas, region. The report contains 18 sheets and 17 tables: 3 sheets are maps showing current-year (2007) water-level altitudes for each aquifer, respectively; 3 sheets are maps showing 1-year (2006-07) water-level changes for each aquifer, respectively; 3 sheets are maps showing 5-year (2002-07) water-level changes for each aquifer, respectively; 4 sheets are maps showing long-term (1990-2007 and 1977-2007) water-level changes for the Chicot and Evangeline aquifers, respectively; 1 sheet is a map showing long-term (2000-2007) water-level change for the Jasper aquifer; 2 sheets are revisions of previously published water-level-altitude maps for the Jasper aquifer for 2000 and 2002, respectively; 1 sheet is a map showing site locations of borehole extensometers; and 1 sheet comprises graphs showing measured compaction of subsurface material at the sites from 1973 or later through 2006, respectively. Tables listing the data used to construct the aquifer-data maps and the compaction graphs also are included.
\end{abstract}

\section{Introduction}

This report is one in an annual series of reports that depicts water-level altitudes and waterlevel changes in the Chicot, Evangeline, and Jasper aquifers, and compaction in the Chicot and Evangeline aquifers in the Houston-Galveston, Texas, region. The Houston-Galveston region comprises Harris, Galveston, Fort Bend, Waller, and Montgomery Counties and adjacent parts of Brazoria, Grimes, Walker, San Jacinto, Liberty, and Chambers Counties. The report was done in cooperation with the Harris-Galveston Subsidence District, the City of Houston, the Fort Bend Subsidence District, and the Lone Star Groundwater Conservation District.

The U.S. Geological Survey (USGS) has published annual reports of water-level altitudes and water-level changes for the Chicot and Evangeline aquifers in the Houston-Galveston region since 1979; and annual reports of same for the Fort Bend subregion (Fort Bend County and adjacent areas) since 1990. The USGS first published a water-level-altitude map for the Jasper aquifer in the greater Houston area (primarily Montgomery County) in 2001.

This report contains maps showing current-year (2007) water-level altitudes for each of the three aquifers; maps showing 1-year (2006-07) water-level changes for each aquifer; maps showing 5-year (2002-07) water-level changes for each aquifer; maps showing long-term 
(1990-2007 and 1977-2007) water-level changes for the Chicot and Evangeline aquifers; a map showing long-term (2000-2007) water-level change for the Jasper aquifer; and revisions of previously published water-level-altitude maps for the Jasper aquifer for 2000 and 2002. The report also contains graphs showing measured compaction of subsurface material at 11 sites from 1973 or later through 2006. Tables listing the data used to construct each of the maps and the compaction graphs also are included.

\section{Geohydrology}

The Chicot aquifer (in Holocene- and Pleistocene-age sediments), Evangeline aquifer (in Pliocene- and Miocene-age sediments), and Jasper aquifer (in Miocene-age sediments) are the three primary aquifers in the Gulf Coast aquifer system (Baker, 1979; 1986). The lowermost Jasper aquifer is separated from the Evangeline aquifer by the Burkeville confining unit. The hydrogeologic units are laterally discontinuous fluvial-deltaic deposits of gravel, sand, silt, and clay that dip and thicken from northwest to southeast. The aquifers thus crop out in bands inland from and approximately parallel to the coast and become progressively more deeply buried and confined toward the coast. The Chicot aquifer outcrop, which comprises the youngest sediments, is the closest of the aquifer outcrops to the coast, followed farther inland by the Evangeline aquifer outcrop and then farthest inland by the Jasper aquifer outcrop.

The Chicot aquifer can be differentiated from the geologically similar Evangeline aquifer on the basis of hydraulic conductivity (Carr and others, 1985, p. 10). The Jasper aquifer can be differentiated from the Evangeline aquifer in the outcrops on the basis of water levels (higher in the Jasper than in the Evangeline) and in the downdip parts of the aquifers on the basis of position relative to the Burkeville confining unit.

The water in the aquifers is fresh (less than 1,000 milligrams per liter dissolved solids concentration) in the region but becomes more saline in the downdip and deeply buried parts of the aquifers near the coast (Baker, 1979). In the natural ground-water-flow system, water recharges the aquifers in the unconfined outcrop areas, moves downward and coastward, and discharges upward as diffuse upward leakage in the confined downdip areas.

The authors express appreciation to the owners and operators of wells throughout the study area. This report could not have been done without their assistance in granting access to wells and providing pertinent information.

\section{Water-Level Altitudes and Water-Level Changes}

Water-level altitudes were obtained by steel tape, by air line, and from reports of well operators. Most wells are pumped once daily, but some are pumped more frequently. Multiple measurements were made when wells were not being pumped; however, antecedent conditions and pumping status of nearby wells were not always known. Most measurements were made in January and February, the months when water levels usually are highest. Water-level altitude is indicated on the maps by contours of equal water-level altitude at various intervals.

For the 1-year change maps, water-level changes were computed by subtracting historical water-level altitudes from current-year water-level altitudes for those wells for which both historical and current-year altitude measurements (water-level pairs) are available. Change is indicated on the maps by differences between 2006 and 2007 water levels shown at well sites. Change on the 1-year maps is indicated by water-level differences at well sites because contouring a surface of numerous closely spaced data points, and honoring every data point, is problematic in places. For the 5-year and long-term change maps, generally fewer data points are available than 
for the 1-year maps, and change can be more readily indicated by contours of equal water-level change at various intervals. Each contoured change map was created by subtracting a raster (gridded) surface of the historical water-level-altitude map, supplemented by additional water levels for that year, from a raster surface of the 2007 water-level-altitude map using a geographical information system (GIS). Contours then were generated from the resultant raster surface. The raster surfaces of the respective maps are created from the water-level data points and water-level contours. Subtraction of the raster surfaces in a GIS provides an objective and unbiased rendition of differences in areas where data points are relatively sparse. However, the method can result in artificial water-level-change features in such areas-nonexistent mounds or depressions-in the contoured map. Each contoured change map was reviewed for such features, and any identified were deleted.

For the Chicot and Evangeline aquifers, maps show approximate water-level altitudes in 2007, water-level changes from 2006 to 2007, and approximate water-level changes from 2002 to 2007, from 1990 to 2007, and from 1977 to 2007 (figs. 1-10). For the Jasper aquifer, maps show approximate water-level altitudes in 2007, water-level changes from 2006 to 2007, and approximate water-level changes from 2002 to 2007 and 2000 to 2007 (figs. 11-14). This report contains two additional maps: a revised Jasper aquifer water-level-altitude map for 2000 (fig. 15), which supersedes the map of Coplin (2001), and a revised Jasper aquifer water-level-altitude map for 2002 (fig. 16), which supersedes the map of Coplin and Lanning-Rush (2002, sheet 11). The two maps were revised on the basis of water-level data for the Jasper aquifer that became available subsequent to publication of the original maps (John Nelson, LBG-Guyton Associates, written commun., 2006).

For the Chicot aquifer maps, 192 water-level measurements were used for the 2007 altitude (table 1), 167 water-level pairs were used for the 2006-07 change (table 2), 141 water-level pairs for the 2002-07 change (table 3), 94 water-level pairs for the 1990-2007 change (table 4), and 52 water-level pairs for the 1977-2007 change (table 5). For the Evangeline aquifer maps, 383 waterlevel measurements were used for the 2007 altitude (table 6), 299 water-level pairs were used for the 2006-07 change (table 7), 270 water-level pairs for the 2002-07 change (table 8), 143 waterlevel pairs for the 1990-2007 change (table 9), and 73 water-level pairs for the 1977-2007 change (table 10). For the Jasper aquifer maps, 91 water-level measurements were used for the 2007 altitude (table 11), 73 water-level pairs were used for the 2006-07 change (table 12), 51 water-level pairs for the 2002-07 change (table 13), and 56 water-level pairs for the 2000-2007 change (table 14).

Three maps, one for each aquifer (appendix), link the locations of wells used to make each map to the tabular data for the respective map by way of sequential index numbers common to both the map and the associated table.

The data used to construct the revised Jasper aquifer water-level-altitude map for 2000 are listed in table 15; and the data used to construct the revised Jasper aquifer water-level-altitude map for 2002 are listed in table 16.

\section{Compaction}

Compaction of subsurface material is measured continuously by 13 borehole extensometers at 11 sites (fig. 17). Graphs of compaction from 1973 or later through 2006 for 12 of the 13 extensometers are shown in figure 18; data for the graphs are listed in table 17. Compaction measured by the shallower of two extensometers at the Clear Lake site is not shown because it is similar to that measured by the deeper extensometer at the site. 


\section{References}

Baker, E.T., Jr., 1979, Stratigraphic and hydrogeologic framework of part of the Coastal Plain of Texas: Texas Department of Water Resources Report 236, 43 p.

Baker, E.T., Jr., 1986, Hydrology of the Jasper aquifer in the southeast Texas Coastal Plain: Texas Water Development Board Report 295, 64 p.

Carr, J.E., Meyer, W.R., Sandeen, W.M., and McLane, I.R., 1985, Digital models for simulation of ground-water hydrology of the Chicot and Evangeline aquifers along the Gulf Coast of Texas: Texas Department of Water Resources Report 289, 101 p.

Coplin, L.S., 2001, Water-level altitudes in wells completed in the Jasper aquifer, greater Houston area, Texas, spring 2000: U.S. Geological Survey Open-File Report 01-147, 2 p.

Coplin, L.S., and Lanning-Rush, Jennifer, 2002, Water-level altitudes 2002 and water-level changes in the Chicot, Evangeline, and Jasper aquifers and compaction 1973-2001 in the Chicot and Evangeline aquifers, Houston-Galveston region, Texas: U.S. Geological Survey Open-File Report 02-134, 15 sheets.

Gabrysch, R.K., 1979, Approximate altitude of water levels in wells in the Chicot and Evangeline aquifers in the Houston area, Texas, spring 1977 and spring 1978: U.S. Geological Survey OpenFile Report 79-334, 4 sheets.

Kasmarek, M.C., 1997, Water-level altitudes in wells completed in the Chicot and Evangeline aquifers, Fort Bend County and adjacent areas, Texas, January-February 1990: U.S. Geological Survey Open-File Report 97-784, 2 sheets.

University of Texas, Bureau of Economic Geology, 1968, Geologic atlas of Texas, Beaumont sheet: Austin, scale 1:250,000.

University of Texas, Bureau of Economic Geology, 1974, Geologic atlas of Texas, Austin Sheet: Austin, scale 1:250,000.

\section{Appendix-Well Location Maps}

-Map showing location of wells, Chicot aquifer.

-Map showing location of wells, Evangeline aquifer.

-Map showing location of wells, Jasper aquifer. 